\title{
Current floristic and phytogeographic knowledge of Mexican Bromeliaceae
}

\author{
Adolfo Espejo Serna y Ana Rosa López-Ferrari ${ }^{1}$ \\ ' Herbario Metropolitano, Departamento de Biología, C.B.S., Universidad Autónoma Metropolitana, Unidad Iztapalapa, \\ Apartado Postal 55-535, 09340 México, D. F., Fax 7244688, e-mail: aes@xanum.uam.mx
}

Received 6-XI-1997. Corrected 28-V-1998. Accepted 19-VI-1998.

\begin{abstract}
A current floristic and phytogeographic knowledge of native Mexican Bromeliaceae is presented. There are 22 genera of Bromeliaceae recorded from the country that include 326 species. The genus Ursulaea with 2 species is endemic to Mexico, while Hechtia with 48 of its 50 species has its principal center of diversity in the country. Tillandsia (175 spp), Hechtia (48 spp) and Pitcairnia (46 spp) are the genera with the greatest number of species. We present a comparative analysis of Mexican Bromeliaceae with that of other American regions that have recently published accounts for the Family, particularly the Mesomerican area, Venezuela, Ecuador, and the Guianas. Our results led us to the conclusion that all these floras should be considered as distinct. We observe a progressive decrease of the Simpson index value related with the remoteness of the Mexican area. A general analysis of the species numbers of Mexican bromeliad genera shows a distinct prefer nce of the speci $s$ for coniferous and oak forests, followed by tropical caducifolious forests. There is also significant representation of the family in other vegetation types such as cloud forests and tropical perennifolious forests. Generally Mexican Bromeliaceae species have scarce and sparse populations and in many $\mathrm{c}$ ses they inhabit cliffs, bluffs and scarps in restricted areas. Concerning the geographic distribution of Mexican genera, $77.27 \%$ are neotropical, $4.54 \%$ are South American and the remainder are Mexican and Central American. The generic endemism is very low (4.54\%), even if we extend the country limits to Megamexico sensu Rzedowsi (1991) it r aches only $13.63 \%$. The family endemism at specific level reaches $63.07 \%$. There are not available data about a specific analysis of the conservation status of Mexican Bromeliaceae, but we can point out that a great number of taxa are only known from the type collection or at the most from the type locality. This can perhaps be attributed in part to the fact that there is a lack of sufficient collections; however, we suppose that several species are surely endangered.
\end{abstract}

Key words: Bromeliaceae, Mexico, Megamexico, Mesoamerica, Neotropic, floristics, phytogeography.

The Bromeliaceae is composed of 61 genera with species numbers surpassing 2700 . The members of the family are generally conspicuous and easily distinguished from other monocotyledons by their water absorbing peltate scales and their polystichous, mostly rosulate leaves with a broad sheathing base. The family is endemic to America, with exception of Pitcairnia feliciana (A. Chev.) Harms \&
Mildbr. which is native to West Africa (Dahlgren et al. 1985 p. 330, Smith \& Downs 1974 p. 57). The great majority of the taxa have a tropical or subtropical distribution and are mostly central and southamerican.

Mexico has the second most richest flora in the Americas, and in the monocots, the Bromeliaceae is fourth in species number after Poaceae, Orchidaceae and Cyperaceae. The 
Bromeliaceae are an important ecological component in Mexico's natural habitats and vegetation types. Furthermore, several species are economically important, and others have local traditional and domestic uses.

In these brief notes, we attempt to summarize the present floristic and ecological knowledge of Mexican Bromeliaceae. Non integrative work on revison of the family for Mexico has been made recently, notwithstanding, partial works are known (Breckenridge 1991, BurtUtley \& Utley 1987, Gardner 1982, 1986, Kiff 1991, Matuda 1952, McVaugh 1989, Smith \& Downs 1974, 1977, 1979). Over time numerous changes in the delimitation of genera and species have been made (Smith \& Kress 1989, 1990, Varadarajan \& Gilmartin 1988a, 1988b, Spencer \& Smith 1993, Read \& Baensch 1994, Utley \& Burt-Utley 1994, Grant 1995a, 1995b), and the taxonomy and nomenclatural situation of the members of the family is at present quite different.

There are 22 genera of Bromeliaceae recorded from Mexico, that include 326 species and 27 varieties and/or subspecies (= 353 taxa) (Espejo \& López-Ferrari 1994) (Table 1). The genera and species numbers are summarized in Table 2. The subfamily best represented at the generic level is Bromelioideae, with 13 of the 37 genera that comprise it. Second is the Tillandsioideae, with five of its seven genera, and finally the Pitcairnioideae, with four of its 17 genera. The subfamily with the greatest number of species is Tillandsioideae, with 203, but the highest percentage of endemism at the species level is in the Pitcairnioideae (81.4\%). The States with the greatest number of genera are Chiapas, Oaxaca, Veracruz and Jalisco;

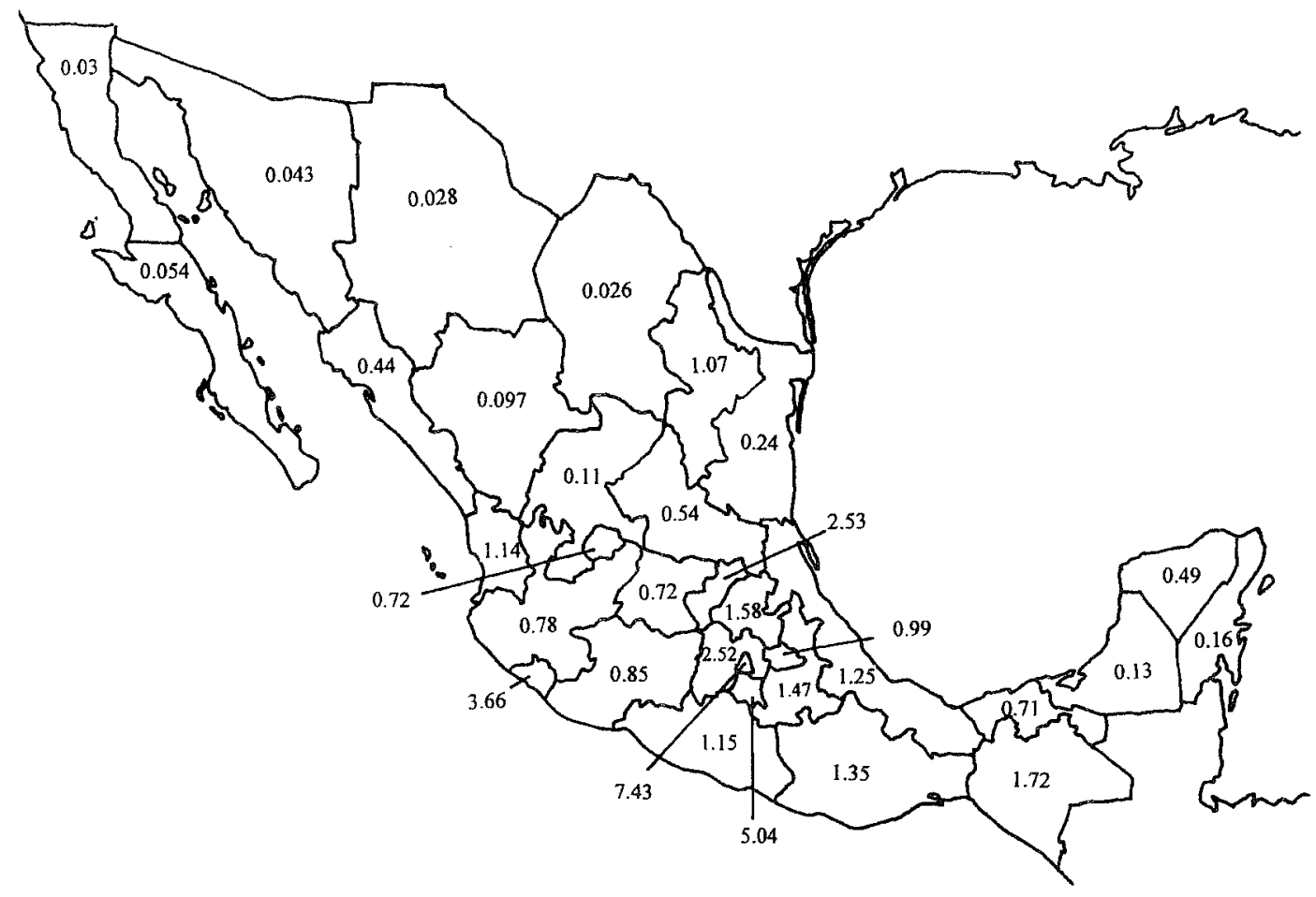

Fig. 1. Number of species/ $1000 \mathrm{~km}^{2}$ by state. 


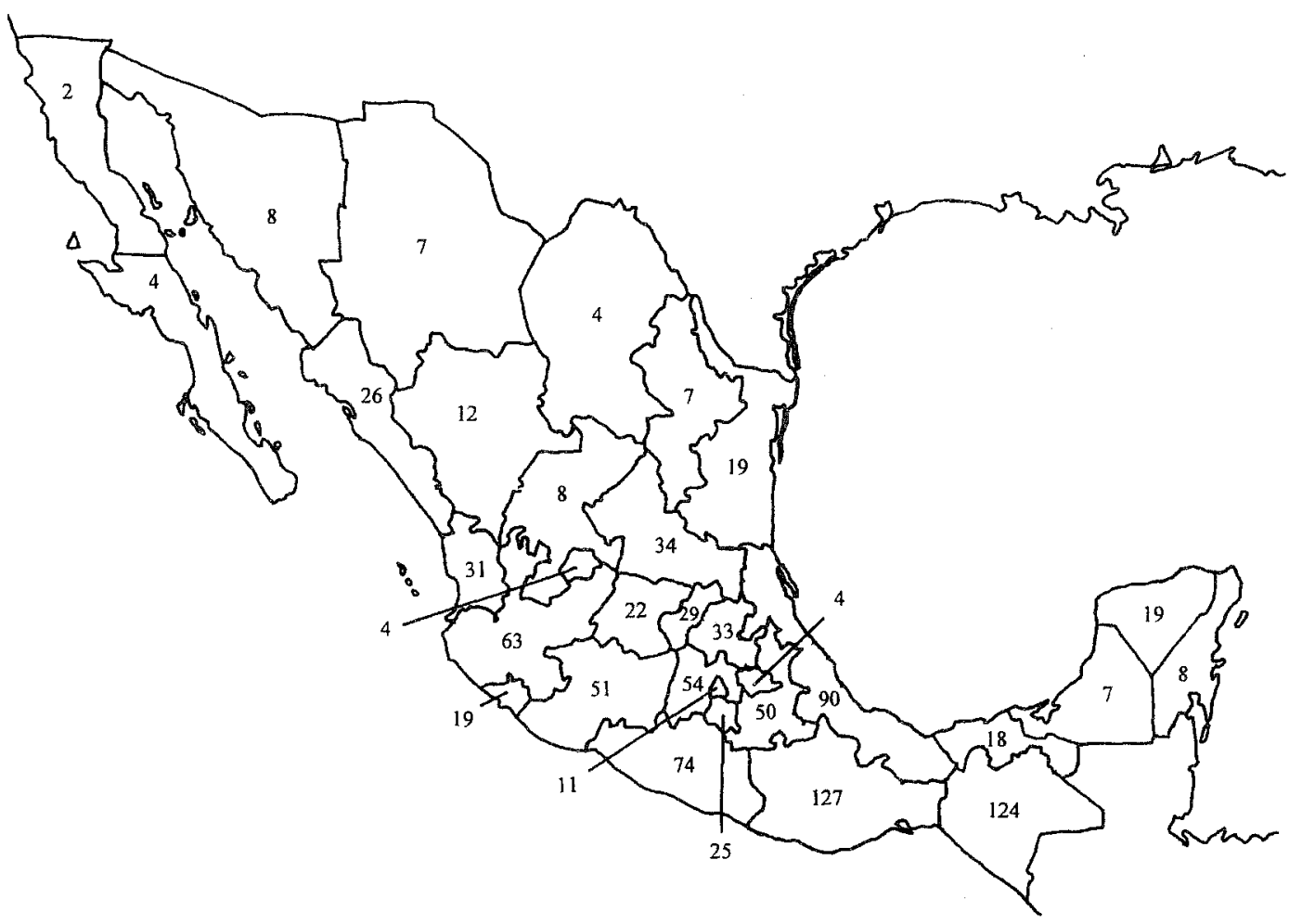

Fig. 2. Number of species by state.

those with the greatest number of species are Oaxaca, Chiapas, Veracruz, Guerrero and Jalisco; and the greatest number of endemic species are in Oaxaca, Guerrero and Chiapas. Nineteen of the thirty two states have endemic species (Table 5). Fig. 1 shows graphically the number of species by $1000 \mathrm{~km}^{2}$ present in each state and Fig. 2 the total species number by state.

In addition, some species of several introduced and/or native genera such as Cryptanthus, Neoregelia, Ortgiesia, Platyaechmea, Tillandsia and Vriesea are cultivated as ornamentals.

We present a comparative analysis of Mexican Bromeliaceae with that of other American regions that have recently published accounts for the Family, particularly the Mesomerican area, Venezuela, Ecuador, and the Guianas.
For the comparison with the Central American region we used Flora Mesoamericana (Utley \& Burt-Utley 1994) which comprises 26 genera (modified in generic delimitations by the authors) and 301 species (Table 6). In Mexico, the subfamily with the greatest number of species is the Tillandsioideae, with 203. Tillandsia and Pitcairnia are the genera with the greatest number of species for their respective subfamilies. Other genera such as Werauhia and Guzmania, both of the Tillandsioideae, have a better representation in the mesoamerican region than in Mexico, with 55 and 34 species respectively.

The biogeographical similarity in the Bromeliaceae between the two areas (Table 6) was calculated with the Simpson similarity index (1943). The value obtained was $43.85 \%$. 
For the case of Venezuela, we use the checklist of the Bromeliaceae published by Holst (1994), which comprises 37 genera (modified in generic delimitations by the authors) and 361 species (Table 7). The index obtained was $8.92 \%$.

For Ecuador we use the data aported by Luther (1989) that we present in Table 8. The index obtained was $6.15 \%$.

Finally, the information about the Guianas (Table 9), was obtained from Boggan et al. (1997) and the following index was obtained: $11.92 \%$.
A brief account of each of the genera found in Mexico follows. Data are based on seven years of field work and library and herbarium study.

\section{Aechmea Ruíz \& Pav.}

This is a genus with 114 species, of which only two occur in Mexico, A. bracteata (Sw.) Griseb. with two varieties and A. matudae L. B.

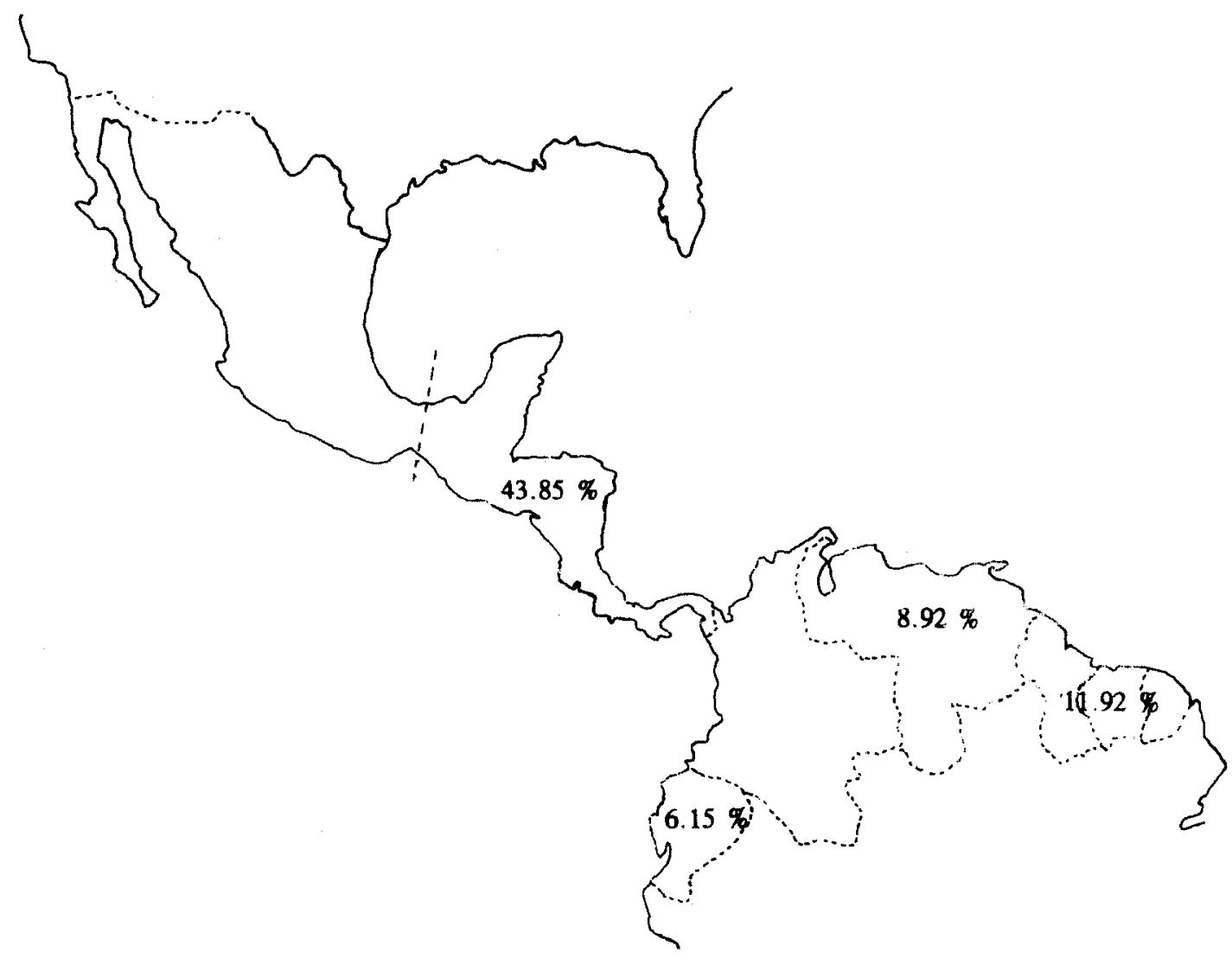

Fig. 3. Simpson's similitude index between the Mexican and other bromeliaceous floras.

Sánchez \& López (1988) propose that the standard critical value for the Simpson's index should be $66.66 \%$. Accordingly, our results led us to the conclusion that all the floras should be considered as distinct. We observe a progressive decrease of the index value related with the remoteness of the Mexican area (Fig 3).
Sm. Both species inhabit rocks or are epiphytic in tropical perennifolious, tropical subcaducifolious or tropical caducifolious forests, from sea level to $1000(-1400 \mathrm{~m})$. A. bracteata grows along both slopes of the country whereas $A$. matudae is known only from the Pacific slope, in Chiapas and Guatemala. 
Recently the generic delimitation of Aechmea has changed and various genera have been segregated, reduced to synonymy or proposed, of which Chevaliera, Macrochordion, Platyaechmea, Podaechmea, Pothuava and Ursulaea are present in Mexico. The genus Aechmea sensu stricto is distinguished from the others of the "Aechmea complex" by floral bracts that are not decurrent and do not form pouches around the flowers.

\section{Ananas Mill.}

The only species present in Mexico of the eight in the genus, is A. comosus (L.) Merr., the pineapple or "Piña". It is a highly variable plant with many forms and cultivars that is widely cultivated in the southeast of the country, mainly in the states of Veracruz, Oaxaca and Chiapas. The fruit is highly prized. In some places it is naturalized.

The natural distribution of Ananas is northcentral South America, in Paraguay, N. Argentina, Brazil, Suriname, Guyana, French Guiana, Venezuela and Colombia. A. comosus evolved in central Brazil, which is the probable center of origin. All the Ananas species are terrestrial and grow between 0 and $1500 \mathrm{~m}$.

\section{Androlepis Brongn. ex Houllet}

The single species of this Central American monotypic genus, A. skinneri (K. Koch) Brongn. ex Houllet, is known in Mexico from only a small area in the state of Chiapas. The species is easy recognized by its apically biappendaged anthers and the naked, yellow petals less than $1 \mathrm{~cm}$ long. It is a large epiphytic species that inhabits tropical perennifolious and tropical subcaducifolious forests from near sea level to $920 \mathrm{~m}$. Androlepis skinneri grows from the Lacandona region in Chiapas to Costa Rica, with a long distance disjunction to Central Perú.

\section{Billbergia Thunb.}

Sixty-two species compose this neotropical genus, with four present in Mexico: $B$. viridiflo$r a \mathrm{H}$. L. Wendl. of the subgenus Billbergia and $B$. chiapensis Matuda, B. pallidiflora Liebm., and $B$. mexicana $\mathrm{Mez}$ of the subgenus Helicodea. B. chiapensis is endemic to Chiapas (Table 5, appendix 1), and known only from the type collection. $B$. viridiflora is recorded only from the southern state of Tabasco, Belize and Guatemala, and is endemic to Megamexico (sensu Rzedowski 1991). B. pallidiflora and $B$. mexicana occur on the Pacific slope of the country from Sinaloa to Chiapas and extend to El Salvador and Nicaragua in Central America.

All the Mexican species of Billbergia are epiphytic or rarely terrestrial or saxicolous, ocurring mostly in tropical perennifolious or tropical caducifolious forests, rarely in oak-pine or thorn forests, from near sea level to $1400 \mathrm{~m}$.

\section{Bromelia L.}

This taxon is composed of 49 species, five of them known from Mexico: $B$. alsodes $\mathrm{H}$. St. John, B. hemisphaerica Lam., B. palmeri Mez, $B$. pinguin L. and B. plumieri (E. Morren) L. B. Sm. The Mexican species are large terrestrial herbs with strongly-armed leaf margins. The fruits of some species locally named "Piñuelas", "Piñuelillas" or "Timbiriches" (i. e. $B$, pinguin L., B. plumieri (E. Morren) L. B. $\mathrm{Sm}$.) are edible or used to prepare beverages and are commonly sold in local markets.

The representatives of the genus inhabit mostly tropical and thorn forests although some species occur in pine-oak forests and xerophilous scrubs (Table 3). Their altitudinal range varies from 0 to $1800 \mathrm{~m}$. In some regions the plants are cultivated and used as live fences. B. palmeri Mez is endemic to Mexico (Table 5, appendix 1) and inhabits Pacific slopes from Jalisco to Oaxaca. 


\section{Catopsis Griseb.}

We have registered from Mexico 15 of the 21 species that comprise this genus, two of which are endemic to the country. (Table 2, appendix 1). The genus is taxonomically complex because of the presence of perfect and/or dimorphic and functionally dioecious flowers, a condition that has caused taxonomic and nomenclatural problems, generating ample synonymy and problems in species delimitation. A revision of the genus is in prepartion (Palací inéd.).

The plants are epiphytic in tropical and temperate forests and rarely in savannahs (Table 3), between 25 and $2700 \mathrm{~m}$.

\section{Chevaliera Gaudich. ex Beer}

Only one species with two varieties of the 23 included in the genus occurs in Mexico. Chevaliera magdalenae André is terrestrial and known from tropical perennifolious forests in Chiapas, Oaxaca and Veracruz in Mexico, and south to Venezuela and Ecuador, between 50 and $640 \mathrm{~m}$. The leaves of Ch. magdalenae are used for the extraction of fibers for the elaboration of rope. The species has the local name of "Pita" or "Pita floja".

\section{Fosterella L. B. Sm.}

This genus is represented in Mexico by the single species $F$. micrantha (Lindl.) L. B. Sm. It is a terrestrial plant that inhabits tropical perennifolious, tropical subperennifolious or cloud forests in the states of Jalisco, Guerrero, Oaxaca, Veracruz and Chiapas in Mexico, and in Guatemala and El Salvador in Central America. The species occurs between 200 and $1200 \mathrm{~m}$.

\section{Greigia Regel}

This genus is mainly South American in distribution, with only six species present in the mesoamerican area. The saxicolous $G$. juareziana L. B. Sm. and G. vanhyningii L. B. Sm. are endemic to Mexico (Table 2, appendix 1). The Mexican species inhabit oak and coniferous forests (Table 3) in Chiapas, Oaxaca and Veracruz between 2100 and $2700 \mathrm{~m}$. The plants of Greigia are easily recognized by carrying their flowers in flattened heads deeply disposed in the axils of the leaves, so their presence is hardly conspicuous.

\section{Guzmania Ruíz \& Pav.}

The genus includes 150 species. Of them $G$. nicaraguensis Mez \& C. F. Baker and G. lingulata (L.) Mez are epiphytic species that inhabit tropical perennifolious and cloud forests in the states of Chiapas and Oaxaca (Table 3). The species grow at altitudes between sea-level and $1800 \mathrm{~m}$. As with Greigia, this genus is mainly South American, and the Mexican species represent the northern limit of the generic distribution.

The unappendaged and connate petals clearly distinguish Guzmania from other generà of the Mexican Tillandsioideae.

\section{Hechtia Klotzsch}

Hechtia is the largest genus in the country after Tillandsia, and moreover, has its principal center of diversity in Mexico. $96 \%$ (48) of its species occur in the country, and $91.5 \%$ (43) of them are endemic (Table 2, appendix 1). Using the Megamexico concept proposed by Rzedowski (1991) the level of endemism reaches $100 \%$. The taxonomy of the genus is not yet clearly understood and a revision is badly needed. Hechtia species are dioicous and this condition, in addition to scarce and/or incomplete collections, has generated many taxonomic and nomenclatural problems.

The species of Hechtia are terrestrial or saxicolous in habit, living mostly in cliffs, bluffs, and precipitous walls in diverse vegetation types, though they prefer tropical caducifolious forests, 
and xerophilous scrubs (Table 3). Their altitudinal range varies from sea-level to $2800 \mathrm{~m}$.

Most species of Hechtia are easily distinguished by their rosettes of spinose-serrate leaves in combination with their unisexual flowers disposed in separate plants.

\section{Hohenbergiopsis L. B. Sm. \& Read}

A monotypic genus, with $H$. guatemalensis (L. B. Sm.) L. B. Sm. \& Read, an epiphytic species, present in the southeastern states of Chiapas and Oaxaca. It occurs in cloud forests (Table 3) at an altitudinal range of 800-1800 m. The filaments are basally connate forming a tube which is adnate to the unappendaged petals. In addition, the pollen dispersed in tetrads making this genus unmistakable.

\section{Macrochordion De Vriese}

Only one of the ten species comprising this genus occurs in Mexico. M. bromeliifolia (Rudge) Beer is found in the southeastern state of Quintana Roo, and inhabits tropical subperennifolious forests (Table 3) near sea-level. It is an epiphytic plant characterized by the presence of yellow-greenish petals that turn blackish after the anthesis.

\section{Pepinia Brongn. ex André}

Pepinia is represented in Mexico by $P$. punicea (Scheidw.) Brongn. ex André and $P$. amblyosperma (L. B. Sm.) G. S. Varad. \& Gilmartin. The former, known only from Chiapas and Tabasco, is a terrestrial plant that grows abundantly on river banks in tropical perennifolious and subperennifolious forests, while the latter is endemic (Table 2, appendix 1) to a small region that includes part of the states of San Luis Potosí, Puebla and Veracruz. It is also a terrestrial plant growing in cloud forests (Table 3). The altitudinal range of the species varies between sea-level and $1000 \mathrm{~m}$. Pepinia had been long-considered a subgenus of Pitcairnia, but recently received generic status (Varadarajan \& Gilmartin 1988a, 1988b). Pepinia is differentiated from Pitcairnia by seed and leaf characteristics. The former have winged seeds and monomorphic leaves while Pitcairnia has biappendiculated seeds and dimorphic or trimorphic leaves.

\section{Pitcairnia L'Hér.}

Pitcairnia is the third best represented genus in Mexico, with 46 of its 266 recognized species growing in the country. The specific endemism reaches $76 \%$ and it is among the highest in the family (Table 2, appendix 1). Most of the species are saxicolous and/or terrestrial and a few are epiphytes. The species grow in diverse vegetation types but mainly in oak and coniferous forests (Table 3), between 100 and $2900 \mathrm{~m}$.

This is an interesting and variable genus that needs the attention of taxonomists to resolve the numerous problems of inter and intraspecific delimitation in several Mexican species groups. Thé brightly coloured and conspicuous inflorescences and flowers of many species of the genus, make it attractive as an ornamental resource.

Platyaechmea (Baker) L. B. Sm. \& W. J. Kress

Eighteen species comprise this small genus recently segregated from Aechmea. Platyachmea is distinguished from other members of the "Aechmea complex" by their decurrent floral bracts that form pouches around the flowers. Grant (1994) points out that the correct name of Platyaechmea should be Hoplophytum but does not make the necessary combinations because he questions the merit of the genus.

Only P. tillandsioides (Mart. ex Schult. \& Schult. f.) L. B. Sm. \& W. J. Kress with 2 varieties, P. tillandsioides var. kienastii (E. Morren ex Mez) L. B. Sm. \& W. J. Kress and P. tillandsioides var. tillandsioides are known from 
Mexico. This epiphytic species has been recorded from the southern states of Oaxaca and Chiapas, growing in tropical perennifolious forests (Table 3) between 280 and $1000 \mathrm{~m}$.

\section{Podaechmea (Mez) L. B. Sm. \& W. J. Kress}

A genus of only four species, three of them known from Mexico: P. galeottii (Baker) L. B. Sm. \& W. J. Kress endemic to Veracruz (Table 2, appendix 1), P. lueddemanniana (K. Koch) L. B. Sm. \& W. J. Kress from Chiapas and Veracruz, and, P. mexicana (Baker) L. B. Sm. \& W. J. Kress from Oaxaca, San Luis Potosí and Veracruz. They are epiphytic and/or saxicolous plants and grow between 20 and $1200 \mathrm{~m}$, in cloud and tropical forests (Table 3 ).

The clearly pedicellate flowers distinguish this genus from the other segregate genera of the "Aechmea complex" in Mexico, which have sessile flowers.

\section{Pothuava Gaudich.}

Represented in Mexico only by Pothuava nudicaulis (L.) Regel, an epiphytic species that grows from sea level to $1140 \mathrm{~m}$, in tropical perennifolious to tropical subpernennifolious forests, in the states of Chiapas, Puebla and Veracruz.

The sole species of Pothuava in Mexico, is distinguished from other genera segregated from Aechmea by its simple, dense and cylindrical inflorescence, its small yellow flowers with free sepals and very small or absent floral bracts.

\section{Racinaea M. A. Spencer \& L. B. Sm.}

A genus with 52 mostly South American species of which only two are present in Mexico, $R$. adscendens (L. B. Sm.) M. A. Spencer \& L. B. Sm. and R. ghiesbreghtii (Baker) M. A. Spencer \& L. B. Sm. The former occurs in Chiapas, Oaxaca and Veracruz and the later from only the Mexican states of Oaxaca and Veracruz and Guatemala. Both species grow in tropical perennifolious and cloud forests (Table 3) between 700 and $2000 \mathrm{~m}$.

Racinaea was recently segregated from Tillandsia (Spencer \& Smith 1993). The set of characters that distinguishes the genus from other tillandsioid genera include its distichously arranged, inconspicuous flowers, asymmetric sepals that are broadest towards the apex, and free or nearly so, stamens and pistil that are included within the corolla, and a short and stout style.

\section{Tillandsia L.}

A very large genus that includes ca. 474 species distributed in tropical and warm-temperate America. The species number reported for Mexico varies according to different authors, so Till (pers. com. 1993) reports 167, Kiff (1991) records 148 and García-Franco (1987) gives 189. Espejo \& López Ferrari (1994) reported 175 species of which $111(63.42 \%)$ are endemic to the country (Table 2, appendix 1).

Tillandsia is known from almost all vegetation types present in Mexico but it is most abundant in tropical caducifolious, oak and coniferous forests (Table 3). Their representatives are almost exclusively epiphytes, and grow from sea-level to upper $3000 \mathrm{~m}$.

There are some groups of species in the genus with problems of taxonomic delimitation in need of carefull revision. In her systematic study of Tillandsia subgenus Tillandsia, Gardner (1982) suggests that the genus should be reclassified in accordance with a more thorough study of living material. In 1986, Gardner proposed the subdivision of Tillandsia into 5 preliminary taxonomic "groups" circumscribed more naturally, based chiefly on floral characters.

Some species of Tillandsia are used locally for food, medicine or ritual purposes, and many others as ornamentals. Some of the common popular names of the Tillandsia species are: "Gallitos", "Heno", "Paxtle", "Tecolumate", "Tecolomé". 


\section{Ursulaea Read \& Baensch}

This is the only bromeliad genus endemic (Table 2, appendix 1) to Mexico. It is composed of only two species, U. macvaughii (L. B. Sm.) Read \& Baensch and U. tuitensis (Magaña \& E. J. Lott) Read \& Baensch (Read \& Baensch, 1994), both known from the western region of the country in the States of Durango, Jalisco and Colima.

Both species grow as epiphytes and/or saxicolous plants in tropical subcaducifolious forests (Table 3 ) dominated by Brosimum, between $500-600 \mathrm{~m}$. Ursulaea species are, with some Tillandsias, among the most beautiful and spectacular members of the family in Mexico.

\section{Vriesia Lindl.}

Of this genus of 194 species only three, are recorded from Mexico V. didistichoides (Mez) L. B. Sm., $V$. heliconioides (Kunth) Hook. ex Walp., and $V$. malzinei $\mathrm{E}$. Morren, only the last one being endemic (Table 2, appendix 1). The Mexican Vriesias, all included in the section Xiphion of the genus, are known from San Luis Potosí, Veracruz, Tabasco, Oaxaca and Chiapas, and the species inhabit chiefly in tropical perennifolius forests and cloud forests (Table 3) between sea-level and $1200 \mathrm{~m}$. In general they are poorly represented in Mexican herbaria.

\section{Werauhia J. R. Grant}

Of the 77 species that comprise this genus, only six are present in Mexico, three of them being endemic (Table 2, appendix 1). W. pectinata (L. B. Sm.) J. R. Grant and W. piycnantha (L. B. Sm.) J. R. Grant, are known from coniferous and oak forests and reaches $2500 \mathrm{~m}$ altitude. W. gladioliflora (H. Wendl.) J. R. Grant., W. nocturna (Matuda) J. R. Grant, W. vanhyningii (L. B. Sm.) J. R. Grant, and W. werckleana (Mez) J. R. Grant inhabit in cloud forests, as well as tropical perennifolious and subcaducifolious forests, in an altitudinal range from 1800 to $2100 \mathrm{~m}$.
The Mexican species of Werauhia are mainly tropical epiphytic plants that grow chiefly in the southeastern states of Chiapas, Oaxaca and Veracruz.

\section{COMMENTS}

In Table 3 the species numbers of Mexican bromeliad genera are presented by vegetation type (sensu Rzedowski 1978, appendix 2). A general analysis of the data shows a distinct preference of the species for coniferous and oak forests, followed by tropical caducifolious forests. There is also significant representation of the family in other vegetation types such as cloud forests and tropical perennifolious forests.

Generally Mexican Bromeliaceae species have scarce and sparse populations and in many cases they inhabit cliffs, bluffs and scarps in restricted areas. However, there are some exceptions, particularly in the cloud forests where the bromeliads are an important component of the epiphytic stratum in addition to families such as orchids, aroids and ferns. To date we do not have a specific analysis of the conservation status of Mexican Bromeliaceae, but we can point out that a great number of taxa are only known from the type collection or at the most from the type locality. This can perhaps be attributed in part to the fact that there is a lack of sufficient collections; however, we suppose that several species are su ely endangered. One additional point to bear in mind here is the high percentage of specific endemism (63.07\%) presented by the family in Mexico (Table 2). It is important to mention that many species are endemic not only at the country level but at the state level (appendix 1).

Concerning the geographic distribution of Mexican genera, $77.27 \%$ are neotropical, 4.54\% are South American and the remainder are Mexican and Central American (Table 4). The generic endemism is very low (4.54\%), even if we extend the country limits to Megamexico sensu Rzedowsi (1991) it reaches only $13.63 \%$. Many of the comments expressed 
in this paper are based on the study of specimens deposited in various herbaria. In general, we observed a poor representation, both in number and in quality, of bromeliads in the Mexican collections, especially evident in genera such as Guzmania, Greigia, Androlepis, Ursulaea, Hechtia, and Pitcairnia.

\section{ACKNOWLEDGMENTS}

We thank Jerzy Rzedowski, Graciela Calderón de Rzedowski, Walter Till, Werner Rauh, Jason R. Grant, and Emily Wood for their critical revision and helpful suggestions on the manuscript. We also express our gratitude to the curators of the herbaria AA, CIIDIR, ENCB, GH, IEB, MEXU, MICH, UAMIZ, and XAL for the facilities given and their kind assistance. This work was partially supported by the Comisión Nacional para el Conocimiento y Uso de la Biodiversidad (CONABIO- P015).

\section{RESUMEN}

Se presenta el estado del conocimiento florístico-fitogeográfico que se tiene actualmente sobre los representantes silvestres de la familia Bromeliaceae para México. Hasta el momento se tienen registrados a nivel nacional 22 géneros representados por 326 especies. Ursulaea género con 2 especies es endémico al país, en tanto que Hechtia tiene su centro principal de radiación en México, ya que 48 de sus 50 especies se presentan en la República Mexicana, siendo 43 de ellas, (91.5\%), endémicas. Los géneros con mayor número de especies son Tillandsia (175 spp), Hechtia (48 spp) y Pitcairnia (46 spp). Se presenta un análisis comparativo de las Bromeliáceas mexicanas con las de otras regiones de América, con base en tratamientos para la familia recientemente publicados, particularmente para el área mesoamericana, Venezuela, Ecuador y las Guyanas. Los resultados de dicho análisis nos permiten concluir que la flora bromeliológica presente en cada área es distinta y que se observa un decremento en el valor del índice de Simpson en relación con la lejanía de las áreas con respecto a México. Asimismo el análisis general de las especies presentes en los diversos tipos de vegetación, muestra una clara preferencia de las mismas por los bosques de coníferas y de encinos seguidos por los bosques tropicales caducifolios. También es significativa su representación en otros tipos de vegetación como los bosques mesófilos y los bosques tropicales perennifolios. Generalmente las especies de
Bromeliáceas mexicanas presentan poblaciones escasas y esparcidas y en muchos casos se las encuentra en riscos y acantilados en áreas muy restringidas. En lo relativo a la distribución geográfica de los géneros mexicanos, el 77.27 $\%$ son neotropicales, el $4.54 \%$ son sudamericanos y el porcentaje restantes pertence a taxa mexicanos y centroamericanos. El endemismo genérico es muy bajo (4.54\%) y aún si extendieramos los límites del país a lo que Rzedowski (1991) llama Megaméxico, sólo alcanzaría un $13.63 \%$. El endemismo de la familia a nivel específico alcanza $63.07 \%$.

\section{REFERENCES}

Breckenridge, F. G. III. 1991. The Tillandsia aspect in Northeastern Mexico. J. Bromeliad Soc. 41: 244-252.

Burt-Utley, K. \& J. F. Utley. 1987. Contributions toward a revision of Hechtia (Bromeliaceae). Brittonia 39: 37-43. f. $1-5$.

Dahlgren, R. M. T., H. T. Clifford \& P. F. Yeo. 1985. The Families of Monocotyledons. Springer Verlag. Berlin. $520 \mathrm{p}$

Espejo, A. \& A. R. López-Ferrari. 1994. Las Monocotiledóneas Mexicanas, una sinopsis florística. 1. Lista de Referencia, parte III. Bromeliaceae, Burmanniaceae, Calochortaceae y Cannaceae. Consejo Nacional de la Flora de México, A. C., Universidad Autónoma Metropolitana y Comisión Nacional para el Conocimiento y Uso de la Biodiversidad. México, D. F. $74 \mathrm{p}$.

García-Franco, J. G. 1987. Las Bromelias de México. Revisión bibliográfica y de herbario. INIREB. Xalapa. $94 \mathrm{p}$.

Gardner, C. S. 1982. A sytematic study of Tillandsia subgenus Tillandsia. Ph. D. dissertation. Texas A \& M University.

Gardner, C. S. 1986. Preliminary classification of Tillandsia based on floral characters. Selbyana 9: 130-146.

Grant, J. R. 1993. New combinations in Mezobromelia and Racinaea (Bromeliaceae: Tillandsioideae). Phytologia 74: 428-430.

Grant, J. R. 1994. The reduction of Platyaechmea under Hoplophytum, and a new name in Tillandsia (Bromeliaceae). Phytologia 77: 99-101.

Grant, J. R. 1995a. The resurrection of Alcantarea and Werauhia a new genus. Akad. Wiss. Abh. Math.Naturwiss. Kl. Trop. Subtrop. Pflanz. 91: 1-57. 
Grant, J. R. 1995b. Addendum to "The resurrection of Alcantarea and Werauhia a new genus" (Bromeliaceae: Tillandsioideae). Phytologia 78: 119.123.

Holst, B. K. 1994. Checklist of Venezuelan Bromeliaceae with notes on species distribution by state and levels of endemism. Selbyana 15: 132-149.

Kiff, L1. F. 1991. A distributional checklist of the genus Tillandsia. Botanical Diversions, Encino, California 93 p.

Luther, H. E. 1989. A provisional checklist od the Bromeliaceae of Ecuador. Phytologia 67: 312-330

McVaugh, R. 1989. Bromeliaceae, in Flora Novo-Galiciana 15: 4-79. University of Michigan. Ann Arbor.

Matuda, E. 1952. Las Bromeliáceas de Chiapas. Anales Inst. Biol. Univ. Nac. México 23: 85-153.

Read, R. W. \& H. Ulrich Baensch. 1994. Ursulaea; A new genus of Mexican Bromeliads. J. Bromeliad Soc. 44: 205-211.

Rzedowski, J. 1978. Vegetación de México. Limusa. México. $432 \mathrm{p}$.

Rzedowski, J. 1991. Diversidad y orígenes de la flora fanerogámica de México. Acta Bot. Mex. 14: 3-21.

Sánchez, O. \& G. López. 1988. A theoretical analysis of some indices of similarity as applied to biogeography. Folia entomológica Mexicana 75: 119-145.

Simpson, G. G. 1943. Mammals and the Nature of Continents. Amer. J. Sci. 241: 1-31.
Smith, L. B. 1959. Three new Greigias from Mexico. Bromeliad Soc. Bull. 9: 51-53.

Smith, L. B. \& Downs, R. J. 1974. Pitcairnioideae (Bromeliaceae), in Flora Neotropica 14: 1-662.

Smith, L. B. \& Downs, R. J. 1977. Tillandsioideae (Bromeliaceae), in Flora Neotropica 14 part 2: 6631492.

Smith, L. B. \& Downs, R. J. 1979. Bromelioideae (Bromeliaceae), in Flora Neotropica 14 part 3: 14932142.

Smith, L. B. \& W. J. Kress. 1989. New or restored genera of Bromeliaceae. Phytologia 66: 70-79.

Smith, L. B. \& W. J. Kress. 1990. New genera of Bromeliaceae. Phytologia 69: 271-275.

Spencer, M. A. \& L. B. Smith. 1993. Racinaea, a new genus of Bromeliaceae (Tillandsioideae). Phytologia 74: 151160.

Utley, J. F. \& K. Burt-Utley. 1994. Bromeliaceae, in Flora Mesoamericana 6: 89-156.

Varadarajan, G. S. \& A. J. Gilmartin. 1988a. Phylogenetic relationships of groups of genera within the subfamily Pitcairnioideae (Bromeliaceae). Syst. Bot. 13: 283-293.

Varadarajan, G. S. \& A. J. Gilmartin. 1988b. Taxonomic realignments within the subfamily Pitcairnioideae (Bromeliaceae). Syst. Bot. 13: 294-299. 


\section{TABLE 1}

Number of genera and species of Bromeliaceae present in Mexico and percentages with respect to the world total.

$\begin{array}{ccccc}\text { Total genera } & \text { Mexican genera } & \text { Total species } & \text { Mexican species } & \text { Mexican taxa } \\ 61 & 22(36.06 \%) & \text { ca. } 2700 & 326(\text { ca. } 12.03 \%) & 353\end{array}$

\section{TABLE 2}

Number of species by genera and subfamily. In the last column the endemic species to Mexico are shown, with the percentages, with respect to the total present in the country.

Subfamily Mexican genera Total species Mexican species

\section{Bromelioidea}

$($ total genera $=37)$

\section{SUBTOTAL}

Tillandsioideae

$($ total genera $=9$ )

114
8
1
62
49
23
28
1
10
18
4
21
2

341

21

150

Aechmeae
Ananas
Androlepis
Billbergia
Bromelia
Chevaliera
Greigia
Hohenbergiopsis
Macrochordion
Platyaechmea
Podaechmea
Pothuava
Ursulaea

13

Catopsis

Guzmania

Racinaea

Tillandsia

Vriesia

Werauhia

6

Fosterella

Hechtia

Pepinia

Pitcairnia

4

$23(37.7 \%)$
50

474

194

77

966

14

50

45

266

\section{SUBTOTAL}

$($ total genera $=61)$
375

1682
$2(1.75 \%)$

$1(12.5 \%)$

$1(100 \%)$

$4(6.45 \%)$

$5(10.2 \%)$

$1(4.35 \%)$

$2(7.14 \%)$

$1(100 \%)$

$1(10 \%)$

$1(5.55 \%)$

$3(75 \%)$

$1(4.76 \%)$

$2(100 \%)$

$25(7.33 \%)$

$15(71.42 \%))$

$2(1.33 \%) 0$

$2(4 \%)$

$175(36.91 \%)$

$3(1.54 \%)$

$6(7.79 \% /)$

$203(21.01 \%)$

$1(7.14 \%)$

$48(96 \%)$

$2(4.44 \%)$

$46(17.29 \%)$

$97(25.86 \%)$

$325(19.32 \%)$
Mexican endemic species (appendix 1)

$$
\begin{gathered}
0 \\
0 \\
0 \\
1(25 \%) \\
1(20 \%) \\
0 \\
2(100 \%) \\
0 \\
0 \\
0 \\
1(33.33 \%) \\
0 \\
2(100 \%) \\
7(28 \%) \\
\\
3(20 \%) \\
0 \\
1(50 \%) \\
111(63.42 \%) \\
3(50 \%) \\
3(50 \%) \\
119(58.62 \%) \\
0 \\
43(91.5 \%) \\
1(50 \%) \\
35(76.09 \%) \\
79(81.4 \%) \\
205(63.07 \%) \\
\\
\\
\\
\\
\end{gathered}
$$


TABLE 3

Number of Bromeliaceae species present in the different vegetation types of Mexico (sensu Rzedowski, 1978).

The numbers in parenthesis shows the percentage with respect to the total number of Mexican species.

\begin{tabular}{|c|c|c|c|c|c|c|c|c|c|c|c|}
\hline & TPF & TSF & TCF & TF & XS & G & OF & $\mathrm{CoF}$ & $\mathrm{ClF}$ & Cul & Unknow \\
\hline Aechmea & $2(100)$ & $2(100)$ & $2(100)$ & & & & & & & & \\
\hline Ananas & & & & & & & & & & $1(100)$ & \\
\hline Androlepis & $1(100)$ & $1(100)$ & & & & & & & & & \\
\hline Billbergia & $1(25)$ & & $2(50)$ & $1(25)$ & & & $1(25)$ & $1(25)$ & & & \\
\hline Bromelia & $1(20)$ & $2(40)$ & $5(100)$ & $3(60)$ & $1(20)$ & & $2(40)$ & I (20) & & & \\
\hline Catopsis & $10(66.6)$ & $5(33.3)$ & $2(13.3)$ & & & $1(6.6)$ & $7(46.6)$ & $4(26.6)$ & $8(53.3)$ & & \\
\hline Chevaliera & $1(100)$ & & & & & & & & & & \\
\hline Fosterella & $1(100)$ & $1(100)$ & & & & & & & $1(100)$ & & \\
\hline Greigia & & & & & & & $2(100)$ & $2(100)$ & & & \\
\hline Guzmania & $2(100)$ & & & & & & & & $2(100)$ & & \\
\hline Hechtia & $3(6.2)$ & & $17(35.4)$ & $7(14: 6)$ & $10(20.8)$ & & $6(12.5)$ & $5(10.4)$ & & & $14(29.1)$ \\
\hline Hohenbergiopsis & & & & & & & & & $1(100)$ & & \\
\hline Macrochordion & & $1(100)$ & & & & & & & & & \\
\hline Pepinia & $1(50)$ & $1(50)$ & & & & & & & $1(50)$ & & \\
\hline Pitcairnia & $4(8.7)$ & $6(13)$ & $8(17.4)$ & & & & $22(47.8)$ & $21(45.6)$ & $9(19.6)$ & & $7(15.2)$ \\
\hline Platyaechmea & $1(100)$ & & & & & & & & & & \\
\hline Podaechmea & $2(66.6)$ & $2(66.6)$ & $1(33.3)$ & & & & & & $1(33.3)$ & & \\
\hline Pothuava & $1(100)$ & $1(100)$ & & & & & & & $1(100)$ & & \\
\hline Racinaea & $2(100)$ & & & & & & & & $2(100)$ & & \\
\hline Tillandsia & $26(14.9)$ & $12(6.9)$ & $53(30.3)$ & $9(5.1)$ & $19(10.9)$ & & 66 (37.7) & $50(28.6)$ & $21(12)$ & & $27(15.4)$ \\
\hline Ursulaea & & $1(50)$ & & & & & $1(50)$ & $1(50)$ & & & \\
\hline Vriesea & $2(66.6)$ & & & & & & & & $1(33.3)$ & & \\
\hline Werauhia & $4(66.6)$ & $1(16.6)$ & & & & & $2(33.3)$ & $2(33.3)$ & $4(66.6)$ & & \\
\hline
\end{tabular}

\section{TABLE 4}

Geographic distribution of the Mexican genera of Bromeliaceae. In the last column the number of genera present in each distribution type and the percentage of the total Mexican taxa that it represents are shown.

Geografic distribution

Neotropical
Genera

Aechmea

Billbergia

Bromelia

Catopsis

Chevaliera

Fosterella

Greigia

Guzmania

Macrochordion

Pepinia

Platyaechmea

Podaechmea

Pothuava

Racinea

Tillandsia

Vriesea

Werauhia

Pitcaimia

Ursulaea

Androlepis

Hechtia

Hohenbergiopsis

Ananas

Ananas
Number and $\%$ of the total present in Mexico
Southamerican

Naturalized
$17(77.27 \%)$

$1(4.54 \%)$

$1(4.54 \%)$

$3(13.63 \%)$

$1(4.54 \%)$

$1(4.54 \%)$ 


\section{TABLE 5}

Number of genera and species by state, and the percentge of each with respect to the national total.

State

$$
\begin{gathered}
\text { Number of } \\
\text { species (\%) (Fig. 2) }
\end{gathered}
$$

\section{Endemic} species (\%)
Area

\begin{tabular}{|c|c|c|}
\hline $1(25 \%)$ & 5589 & 0.72 \\
\hline 0 & 69021 & 0.03 \\
\hline 0 & 73475 & 0.054 \\
\hline 0 & 50812 & 0.13 \\
\hline $16(12.9 \%)$ & 72211 & 1.72 \\
\hline 0 & 244938 & 0.028 \\
\hline $1(25 \%)$ & 149982 & 0.026 \\
\hline $3(15.78 \%)$ & 5191 & 3.66 \\
\hline 0 & 1479 & 7.43 \\
\hline $1(8.33 \%)$ & 123181 & 0.097 \\
\hline 0 & 30575 & 0.72 \\
\hline $23(31.08 \%)$ & 64281 & 1.15 \\
\hline $1(3.03 \%)$ & 20813 & 1.58 \\
\hline $10(15.87 \%)$ & 80836 & 0.78 \\
\hline $7(12.96 \%)$ & 21355 & 2.52 \\
\hline $6(11.76 \%)$ & 59928 & 0.85 \\
\hline $1(4 \%)$ & 4960 & 5.04 \\
\hline 0 & 26979 & 1.14 \\
\hline 0 & 64924 & 1.07 \\
\hline $26(20.47 \%)$ & 93952 & 1.35 \\
\hline $5(10 \%)$ & 33902 & 1.47 \\
\hline $1(3.44 \%)$ & 11449 & 2.53 \\
\hline 0 & 50212 & 0.16 \\
\hline $3(8.8 \%)$ & 63068 & 0.54 \\
\hline $3(11.53 \%)$ & 58328 & 0.44 \\
\hline 0 & 182052 & 0.043 \\
\hline 0 & 25267 & 0.71 \\
\hline $1(5.26 \%)$ & 79384 & 0.24 \\
\hline 0 & 4016 & 0.99 \\
\hline $6(6.66 \%)$ & 71699 & 1.25 \\
\hline 0 & 38402 & 0.49 \\
\hline $3(37.5 \%)$ & 73252 & 0.11 \\
\hline
\end{tabular}
in $\mathrm{km}^{2}$
No. species/ $1000 \mathrm{Km}^{2}$ (Fig. 1)

$\begin{array}{lc}\text { Sonora } & 2(9.09 \%) \\ \text { Tabasco } & 8(36.36 \%) \\ \text { Tamaulipas } & 5(22.72 \%) \\ \text { Tlaxcala } & 1(4.54) \\ \text { Veracruz } & 16(72.72) \\ \text { Yucatán } & 5(22.72) \\ \text { Zacatecas } & 2(9.09)\end{array}$




\section{TABLE 6}

Comparative species number of Mexican and Mesoamerican Bromeliaceae.

Genera Total species Mexican species $\quad$ Mesoamerican species $^{1} \quad$ Shared species

BROMELIOIDEAE

$($ total genera $=37)$

Aechmea

Ananas

Androlepis

Araeococcus

Billbergia

Bromelia

Chevaliera

Greigia

Hohenbergiopsis

Macrochordion

Platyaechmea

Podaechmea

Pothuava

Ronnbergia

Ursulaea

SUBTOTAL

357

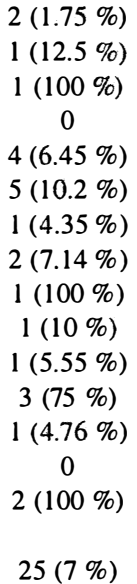

$12(10.53 \%)$

8

1

TILLANDSIOIDEAE

(total genera $=9$ )

Catopsis

Guzmania

Mezobromelia

Racinaea

5

Racinaea

50

Vriesea

474

Werahuia

194

$1(12.5 \%)$

$1(20 \%)$

$4(6.45 \%)$

$5(10.2 \%)$

$3(13.04 \%)$

$6(21.43 \%)$

$1(100 \%)$

$1(10 \%)$

$1(5.55 \%)$

$2(50 \%)$

$4(19.05 \%)$

$2(18.18 \%)$

0

$44(12.32 \%)$

20

SUBTOTAL

PITCAIRNIOIDEAE

$($ total genera $=17)$

Fosterella

Hechtia

Pepinia

Pitcaimia

Puya 186

SUBTOTAL

1889

$$
\begin{gathered}
1(7.14 \%) \\
48(96 \%) \\
2(4.44 \%) \\
46(17.29 \%) \\
2(1.08 \%)
\end{gathered}
$$

$1(7.14 \%)$

$6(12.50 \%)$

$2(4.44 \%)$

$38(14.29 \%)$

0

$97(17.29 \%)$

$49(8.73 \%)$

$325(17.2 \%)$

$301(15.93 \%)$

132

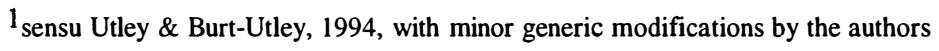


TABLE 7

Comparative species number of Mexican and Venezuelan Bromeliaceae.

Genera Total species $\quad$ Mexican species $\quad$ Venezuelan species $^{1} \quad$ Shared species

BROMELIOIDEAE

$($ total genera $=37)$

Aechmea

Ananas

Androlepis

Araeococcus

Bromelia

Chevaliera

Greigia

Hohenbergia

Hohenbergiopsis

Lamprococcus

Macrochordion

Neoregelia

Platyaechmea

Podaechmea

Pothuava
Billbergia

Ursulaea

SUBTOTAL

TILLANDSIOIDEAE

Catopsis

Glomeropitcairnia

Guzmanial

Mezobromelia

Racinaea

Tillandsia

Vriesea

Werahuia

SUBTOTAL

PITCAIRNIOIDEAE

(total genera $=17$ )

Ayensua

Brewcaria

Brocchinia

Connellia

Fosterella

Hechtia

Lindmania

Navia

Pepinia

Pitcairnia

Puya

Steyerbromelia

SUBTOTAL

TOTAL (total genera $=9$ )
$2(1.75 \%)$
$1(12.5 \%)$
$1(100 \%)$

0

$4(6.45 \%)$

$5(10.2 \%)$

$1(4.35 \%)$

$2(7.14 \%)$

0

$1(100 \%)$

0

$1(10 \%)$

0

$1(5.55 \%)$

$3(75 \%)$

$1(4.76 \%)$

$2(100 \%)$

$25(5.05 \%)$

$21(18.4 \%)$

$3(37.5 \%)$

$2(40 \%)$

$3(4.83 \%)$

$6(12.24 \%)$

$1(4.35 \%)$

$5(17.85 \%)$

$1(2.5 \%)$

$$
0
$$

$3(23 \%)$

$1(10 \%)$

$4(4.16 \%)$

$4(22.22 \%)$

$$
0
$$

$1(4.76 \%)$

0

$55(11.11 \%)$

$$
4(19 \%)
$$$$
1(50 \%)
$$

$28(18.66 \%)$

$2(40 \%)$

$6(12 \%)$

$49(10.33 \%)$

$24(12.37 \%)$

$5(6.49 \%)$

$119(12.23 \%)$

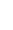

$1(100 \%)$

$2(100 \%) \quad 0$

$15(83.33 \%)$

$5(100 \%) \quad 0$

$$
1(7.14 \%)
$$$$
48(96 \%)
$$$$
0
$$$$
0
$$$$
0
$$$$
2(4.44 \%)
$$$$
46(17.29 \%)
$$$$
0
$$$$
0
$$

$97(13.41 \%)$$$
0
$$

$33(94.28 \%)$

$79(80.6 \%)$

$15(33.33 \%)$

$8(4.30 \%)$

$3(100 \%)$

187 (25.86\%)

$361(16.47 \%)$

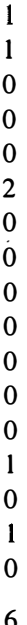

3

0

0

14

1

21
$26(9.77 \%)$$$
0
$$

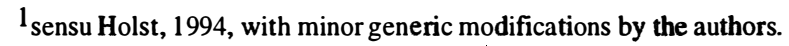




\section{TABLE 8}

Comparative species number of Mexican and Ecuadorian Bromeliaceae.

Genera Total species $\quad$ Mexican species $\quad$ Ecuadorian species ${ }^{1} \quad$ Shared species

BROMELIOIDEAE

$($ total genera $=37)$

Aechmea

Ananas

Androlepis

Billbergia

Bromelia

Chevaliera

Greigia

Hohenbergiopsis

Macrochordion

Neoregelia

Platyaechmea

Podaechmea

Pothuava

Ronnbergia

Ursulaea

SUBTOTAL

114

8

62

49

23

28

1

10

96

18

4

21

11

2

448

TILLANDSIOIDEAE

(total genera $=9$ )

Catopsis

Guzmania

Mezobromelia

Racinaea

Tillandsia

Vriesea

Werauhia

SUBTOTAL

PITCAIRNIOIDEAE

$($ total genera $=17)$

Fosterella

Hechtia

Pepinia

Pitcairnia

Puya

SUBTOTAL

1980
$1(7.14 \%)$

$48(96 \%)$

$2(4.44 \%)$

$46(17.29 \%)$

0

$97(17.29 \%)$

$325(16.41 \%)$

\author{
$18(15.78 \%)$ \\ $4(50 \%)$ \\ $3(4.83 \%)$ \\ $2(4.08 \%)$ \\ $4(17.4 \%)$ \\ $4(14.3 \%)$ \\ 0 \\ 0 \\ $5(5.2 \%)$ \\ $7(38.9 \%)$ \\ $1(25 \%)$ \\ $5(23.8 \%)$ \\ $2(18.18 \%)$ \\ 0
}

$55(12.27 \%)$

$3(14.28 \%)$

$74(49.33 \%) \quad 2$

$4(80 \%) \quad 0$

$28(56 \%) \cdot 0$

$116(24.47 \%) \quad 5$

$12(6.18 \%)$

$6(7.79 \%)$

$243(25.02 \%) \quad 12$

12

$\begin{array}{cc}0 & 0 \\ 0 & 0 \\ 4(8.9 \%) & 0 \\ 45(16.9 \%) & 1 \\ 22(1.8 \%) & 0\end{array}$

$71(12.65 \%)$

$369(18.63 \%) \quad 20$

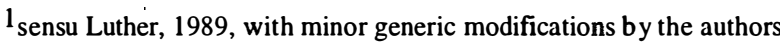


TABLE 9

Comparative species number of Mexican and Guianan Bromeliaceae.

Genera

Total species Mexican species
Guianan (Guyana,Surinam, French Guiana) species 1

BROMELIOIDEAE

$($ total genera $=37)$

Aechmea

Ananas

Androlepis

Araeococcus

Billbergia

Bromelia

Chevaliera

Disteganthus

Greigia

Hohenbergia

Hohenbergiopsis

Lamprococcus

Macrochordion

Platyaechmea

Podaechmea

Pothuava

Ursulaea

SUBTOTAL

114
8
1
5
62
49
23
3
28
40
1
13
10
18
4
21
2
402

$$
\begin{gathered}
2(1.75 \%) \\
1(12.5 \%) \\
1(100 \%) \\
0 \\
4(6.45 \%) \\
5(10.2 \%) \\
1(4.35 \%) \\
0 \\
2(7.14 \%) \\
0 \\
1(100 \%) \\
0 \\
1(10 \%) \\
1(5.55 \%) \\
3(75 \%) \\
1(4.76 \%) \\
2(100 \%) \\
25(6.21 \%)
\end{gathered}
$$

\author{
$18(15.8 \%)$ \\ $5(62.5 \%)$ \\ 0 \\ $3(60 \%)$ \\ $5(8.1 \%)$ \\ $13(26.53)$ \\ 2 ( $8.7 \%)$ \\ $3(100 \%)$ \\ 0 \\ $1(2.5 \%)$ \\ 0 \\ $1(7.7 \%)$ \\ $1(10 \%)$ \\ $2(11.11 \%)$ \\ 0 \\ $1(4.76 \%)$
}

0

$55(13.7 \%)$

Shared species

$2(9.52 \%)$

$13(8.66 \%)$

$2(40 \%) \quad 0$

$4(8 \%) \quad 0$

$20(4.21 \%) \quad 6$

$10(5.15 \%)$

$5(6.49 \%)$

Werahuia

$175(36.91 \%)$

$4(2.06 \%)$

$5(6.49 \%)$

$56(5.76 \%)$

11

PITCAIRNIOIDEAE

$($ total genera $=17)$

Brocchinia

Connellia

203 (20.9\%)

1

$$
0
$$

2

0$$
0
$$$$
0
$$$$
0
$$$$
1
$$$$
1
$$$$
1
$$$$
6
$$

Fosterella

Hechtia

Lindmania

Navia

Pepinia

Pitcairnia

0
0

$48(96 \%)$

0

0 .

$2(4.44 \%)$

$46(17.29 \%)$

7 (38.9\%)

$4(80 \%)$

0

0

$11(11.22 \%)$

$8(17.8 \%)$

$6(2.25 \%)$

$40(7.53 \%)$

$151(7.93 \%)$

18

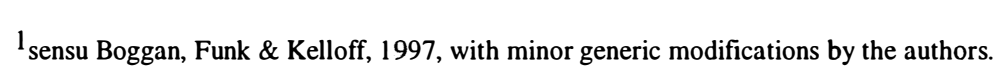




\section{APPENDIX 1}

Mexican endemic species

In the cases of statal endemism, it is indicated in parenthesis the name of the respective state

\section{Billbergia}

B. chiapensis Matuda [Chiapas]

Bromelia

B. palmeri Mez

\section{Catopsis}

C. compacta $\mathrm{Mez}$

C. minimiflora Matuda [Chiapas]

C. mexicana L. B. Sm. [México]

\section{Greigia}

G. juareziana L. B. Sm.

G. vanhyningii L. B. Sm.

\section{Hechtia}

H. argentea Baker [Querétaro]

H. caerulea (Matuda) L. B. Sm.

H. capituligera Mez [San Luis Potosí]

$H$. carlsoniae Burt-Utley \& Utley [Guerrero]

H. caudata L. B. Sm. [Oaxaca]

H. confusa L. B. Sm. [Puebla]

H. conzattiana L. B. Sm. [Oaxaca]

H. desmetiana (hort. ex Baker) Mez [Chiapas]

H. elliptica L. B. Sm. [Chihuahua]

H. epigyna L. B. Sm. [Tamaulipas]

$H$. fosteriana L. B. Sm. [Oaxaca]

$H$. fragilis Burt-Utley \& Utley

H. galeottii Mez [Oaxaca]

H. gayii L, W. Lenz

H. glabra Brandegee [Veracruz]

H. glauca Burt-Utley \& Utley [Michoacán]

H. iltisii Burt-Utley \& Utley [Jalisco]

H. jaliscana L. B. Sm. [Jalisco]

H. laevis L. B. Sm. [Colima]

H. lanata L. B. Sm. [Oaxaca]

H. laxissima L. B. Sm. [Michoacán]

P. flavescentia Matuda [Guerrero]

P. foliacea L B. Sm. [Michoacán]

$P$. hintoniana L. B. Sm. [México]

P. karwinskyana Schult \& Schult $\mathrm{f}$.

P. lanosisepala Matuda [Guerrero]

P. leprosa L. B. Sm. [Guerrero]

P. loki-schmidtii Rauh \& Barthlott [Jalisco]

P. matudae L. B. Sm. [Chiapas]

$P$. micheliana André [Michoacán]

P. micropoda L. B. Sm. [México]

P. modesta L. B. Sm. [Guerrero]

P. monticola Brandegee [Sinaloa]

P. mooreana L. B. Sm. [Guerrero]

P. oaxacana L. B. Sm.

P. ochroleuca (K. Koch \& Bouché) Baker

\author{
H. lindmaniodes L. B. Sm [Veracruz] \\ H. lundelliorum L. B. Sm. \\ H. lyman-smithii Burt-Utley \& Utley [Oaxaca] \\ H. macdougallii L. B. Sm. [Oaxaca] \\ H. marnier-lapostollei L. B. Sm. [México] \\ H. matudae L. B. Sm. \\ H. melanocarpa L. B. Sm. [Guerrero] \\ H. mexicana L. B. Sm. [San Luis Potosí] \\ H. meziana L. B. Sm. \\ H. montana Brandegee \\ H. moorena L. B. Sm. [Guerrero] \\ $H$. pedicellata S. Watson [Jalisco] \\ $H$. podantha $\mathrm{Mez}$ \\ $H$. pumila Burt-Utley \& Utley [Guerrero] \\ H. reflexa L. B. Sm. [Michoacán] \\ H. reticulata L. B. Sm. [Colima] \\ $H$. rosea $\mathrm{E}$. Morren ex Baker \\ H. roseana L. B. Sm. [Puebla] \\ H. sphaeroblasta B. L. Rob. [Guerrero] \\ H. stenopetala Klotzsch \\ $H$. suaveolens $\mathrm{E}$. Morren ex $\mathrm{Mez}$ \\ H. subalata L. B. Sm. \\ H. tillandsioides (André) L. B. Sm. \\ H. zacatecae L. B. Sm. [Zacatecas]
}

Pepinia

P. amblyosperma (L. B. Sm.) G.S. Varad \& Gilmartin

Pitcairnia

P. abundans L. B. Sm.

P. breedlovei L. B. Sm. [Chiapas]

P. chiapensis Miranda [Chiapas]

P. colimenis L. B. Sm. [Colima]

P. compostela McVaugh

P. cylindrostachya L. B. Sm.

$P$. densiflora Brongn. ex Lern.

T. beutelspacheri Matuda [Chiapas]

T. bochilensis Ehlers [Chiapas]

T. bourgaei Baker

T. califanii Rauh [Puebla]

T. callichroma L. Hrom. [Oaxaca]

T. calothyrsus Mez

T. capistraonoensis Ehlers \& W. Weber

T. carlos-hankii Matuda

T. carlsoniae L. B. Sm. [Chiapas]

T. chaetophylla $\mathrm{Mez}$

T. chiapensis C. S. Gardner [Chiapas]

T. circinnatoides Matuda

T. cossonii Baker

T. cretacea L. B. Sm.

T. deppeana Steud. 
P. palmeri S. Watson

P. pteropoda L. B. Sm.

$P$. ringens Klotzsch

P. roseana $\mathrm{L}$. B. Sm.

P. schiedeana Baker

P. secundiflora L. B. Sm. [Chiapas]

P. sordida L. B. Sm. [Guerrero]

P. tabuliformis Linden

P. tillandsioides L. B. Sm. [Guerrero]

$P$. undulata (hort. ex Beer) Scheidw.

$P$. vallisoletana Lex.

$P$. virginalis Utley \& Burt-Utley [Oaxaca]

P. xanthocatyx Mart. [San Luis Potosí]

\section{Podaechmea}

P. galeottii (Baker) L. B. Sm. \& W. J. Kress

\section{Tillandsia}

T. achyrostachyz E. Morren ex Baker

T. aguascalientensis C.S. Gardner [Aguascalientes]

T. albida Mez \& Purpus

T. alfredo-lauii Rauh \& J. Lehm. [Hidalgo]

T. alvareziae Rauh [Veracruz]

T. andrieuxii (Mez) L. B. Sm.

T. atrococcinea Matuda [Oaxaca]

T. atroviridipetala Matuda

T. belloensis $\mathrm{W}$. Weber

T. jaliscopinicola L. Hrom. \& P. Schneid. [Jalisco]

T. juerg-rutschmannii Rauh [Chiapas]

T. kalmbacheri Matuda [Guerrero]

T. karwinaskyana Schult. \& Schult. f.

T. kirchho ffiana Witm.

T. kalusii Ehlers [Chiapas]

T. langlasseana Mez [Michoacán]

T. laui Matuda

T. lepidosepala L. B. Sm.

T. leucolepis L. B. Sm. [Oaxaca]

T. macdougallii L. B. Sm.

T. macrochlamys Baker

T. makrinii L. Hrom. [Oaxaca]

T. marabascoensis Ehlers \& Lautner

T. maritima Matuda

T. mauryana L. B. Sm.

T. mazatlanesis Rauh [Sinaloa]

T. mirabilis L. Hrom. [Guerrero]

$T$ milaensis W. Weber \& Ehlers [Oaxaca]

T. mooreana L. B. Sm.

T. nidus Rauh \& J. Lehm.

T. nolleriana Ehlers [Oaxaca]

T. novakii $\mathrm{H}$. Luther [Veracruz]

T. nuyooensis Ehlers [Oaxaca]

T. oaxacana L. B. Sm.

T. ortgiesiana E. Morren ex Mez [Guerrero]

T. pacifica Ehlers [Jalisco]

T. pamelae Rauh [Jalisco]
T. diguetti Mez \& Rol-Goss.

T. drepanoclada Baker

T. dressleri L. B. Sm. [Sinaloa]

T. dugesii Baker

T. durangensis Rauh \& Ehlers

T. ehlersiana Rauh [Chiapas]

T. eistetteri Ehlers

T. elizabethae Rauh

T. erubescens Schltdl.

T. exserta Fernald

T. ferrisiana $\mathrm{L}$. B. Sm.

T. flavobracteata Matuda [Veracruz]

T. foliosa M. Martens \& Galeotti

T. fresnilloensis W. Weber \& Ehlers [Zacatecas]

T. fuchsii W. Till

T. gracillima L. B. Sm. [Puebla]

T. graebneri Mez [Veracruz]

T. guenther-nolleri Ehlers

T. guerreroensis Rauh [Guerrero]

T. hammeri Rauh \& Ehlers [Oaxaca]

T. hetrophylla F. Morren

T. hintoniana L. B. Sm. [México]

T. hubertiana Matuda [Guerrero]

T. ignesiae $\mathrm{Mez}$

T. ilseana W. Till, Halbritter \& Zecher [Guerrero]

\section{T. intermedia $\mathrm{Mez}$}

T. intumescens $\mathrm{L}$. B. Sm.

T. socialis L. B. Sm. [Chiapas]

T. subinflata L. B. Sm. [Zacatecas]

T. sueae Ehlers

T. superinsignis Matuda [México]

T. supermexicana Matuda [Guerrero]

T. thyrsigera E. Morren ex Baker [México]

T. tillii Ehlers [Jalisco]

T. tortilis Klotsch ex Baker

T. trauneri L. Hrom. [Guerrero]

T. ventanaensis Ehlers \& Koide

T. vernardoi Rauh [Oaxaca]

T. violacea Baker

T. vriesioides Matuda [Chiapas]

T. weberi L. Hrom. \& P. Scheneid. [Jalisco]

T. wuelfinghoffii Ehlers [Oaxaca]

T. yerba-santae Ehlers [Oaxaca]

Usulaea

U. macvaughii (L. B. Sm.) Read \& Baensch

U. tuitensis (Magaña \& E. J. Lott) Read \& Baensch [Jalisco]

Vriesia

V. malzinei E. Morren

\section{Werauhia}

W. werckleana (Mez) J. R: Grant [Chiapas]

W. noctura (Matuda) J. R. Grant [Oaxaca]

W. vanhyningii (L. B. Sm.) J. R. Grant [Oaxaca] 


\author{
T. paraisoensis Ehlers [Guerrero] \\ T. parryi Baker \\ T. pentasticha Rauh \& Wülfinghoff [Guerrero] \\ T. plumosa Baker \\ T. prodigiosa [Lem.] Baker \\ T. pseudosetacea Ehlers \& Rauh [Oaxaca] \\ T. pueblensis L. B. Sm. [Puebla] \\ T. quaquaflorifera Matuda [Guerrero] \\ T. rectifolia C. A. Wiley \\ T. rhodocephala Ehlers \& Koide \\ T. roland-gosselinii \\ T. roseoscapa Matuda \\ T. roseospicata Matuda \\ T. rothii Rauh \\ T. schazlii Rauh [Oaxaca] \\ T. schsteri Rauh [Oaxaca] \\ T. setiformis Ehlers [Oaxaca]
}

